\title{
AMINO ACID PROFILE OF A BASIDIOMYCETOUS EDIBLE MUSHROOM-LENTINUS SAJOR-CAJU
}

\author{
LATA, NARENDER SINGH ATRI
}

Department of Botany, Punjabi University, Patiala, 147002, Punjab, India

Email: narinderatri04@gmail.com

Received: 02 Apr 2017 Revised and Accepted: 22 Jul 2017

\begin{abstract}
Objective: In this paper amino acid profile of Lentinus sajor-caju (Fr.) Fr., a basidiomycetous mushroom has been investigated.

Methods: During the evaluation 15 amino acids (lysine, aspartic acid, serine, threonine, glutamic acid, cysteine, glycine, alanine, valine, methionine, isoleucine, leucine, tyrosine, phenylalanine and histidine) were determined from the dried sample of Lentinus sajor-caju by following the standard technique of biochemistry using ion-exchange chromatography.
\end{abstract}

Results: The total amino acid content has been evaluated at $18.82 \mathrm{~g} / 100 \mathrm{~g}$. Amongst the evaluated amino acids, exogenous amino acid lysine (6.66 $\mathrm{g} / 100 \mathrm{~g}$ ) is preponderantly present in comparison to all other amino acids. The essential amino acid (EAA) index (44.64\%) and biological value $(\mathrm{BV}=36.93 \%)$ has also been determined for the examined sample.

Conclusion: Lentinus sajor-caju (Fr.) Fr. is a potential source of quality protein with a substantial proportion of exogenous and endogenous amino acids.

Keywords: Lentinus sajor-caju, Amino acid, Nutritional value

(C) 2017 The Authors. Published by Innovare Academic Sciences Pvt Ltd. This is an open access article under the CC BY license (http://creativecommons.org/licenses/by/4.0/] DOI: http://dx.doi.org/10.22159/ijpps.2017v9i9.18856

\section{INTRODUCTION}

Mushrooms have been recognized for their nutritional and nutraceutically properties because of their inherent composition. They are rich in essential nutrients including carbohydrates, proteins, vitamins, minerals, antioxidants and variety of bioactive components [1-4]. Because of the nutritional and medicinally important components, mushrooms are considered as functional foods worldwide [3] and can be compared favourably with the food value of milk, egg, meat and commonly consumed vegetables [5-9]. A number of Indian workers [6, 10-19] evaluated a variety of cultivated and wild edible mushrooms for their nutritional and nutraceutically profile including amino acids which are monomeric units of proteins and serve as antioxidant, energy metabolites and precursors of many biologically important nitrogen containing compounds [4, 20-21].

Lentinus sajor-caju (Fr.) Fr. is one such mushroom which is widely consumed in India $[22,23]$ and abroad $[24,25]$. It is a basidiomycetous mushroom which grows in great abundance on dead and fallen branches, tree trunks and even on buried roots [26]. It is of common occurrence in the foot hills of North-West India and is being collected locally for consumption. So as to look into its culinary credentials amino acid profiling was done from the dried sporophores of the mushroom obtained in the laboratory through cultivation.

\section{MATERIALS AND METHODS}

\section{The materials}

The culture of Lentinus sajor-caju (Fr.) Fr. mushroom was raised through tissue culture from the sporophores collected from the wild. Subsequently, cultivation studies were undertaken under laboratory conditions so as to raise the sporophores. The mature sporophores were harvested and dried in a hot air drier at $40 \pm 1{ }^{\circ} \mathrm{C}$ [27] which was subsequently used for amino acid profiling.

\section{Reagents and chemicals}

All reagents and chemicals were of analytical grade. Amino acid standards, ninhydrin, hydrindantin, dimethyl sulfoxide were purchased from SIGMA-Aldrich; phenol, acetic acid, trisodium citrate dihydrate, sodium hydroxide, lithium hydroxide, lithium acetate dihydrate from FLUKA and $\mathrm{HCl}$ 30\% from MERCK.

\section{Solution preparation}

The following solutions were prepared:

\section{Eluent A}

$19.6 \mathrm{~g}$ trisodium citrate dihydrate was dissolved in $800 \mathrm{ml}$ ultrapure water. $5 \mathrm{ml}$ thiodiglycol, $1 \mathrm{~g}$ phenol crystals and $16 \mathrm{ml} \mathrm{HCl}$ were added to it. $2.2 \mathrm{pH}$ was adjusted with $\mathrm{HCl}$ or $\mathrm{NaOH}$ solution. Raised the volume up to $1 \mathrm{~L}$ with water. This was used as elution buffer and extraction of amino acid standards.

\section{Eluent B}

$1.25 \%$ lithium hydroxide and $0.1 \%$ phenol were dissolved in ultrapure water. It was used for column regeneration.

\section{Ninhydrin reagent}

$4.0 \mathrm{~g}$ ninhydrin, $0.16 \mathrm{~g}$ hydrindantin were taken in bottle sparged with Argon/Nitrogen, $100 \mathrm{ml}$ dimethylsulfoxide was poured and 100 $\mathrm{ml} 2 \mathrm{~mol} / \mathrm{l}$ lithium acetate buffer (pH 5.2) was slowly dropped into the bottle. Ninhydrin reagent was stored at $4{ }^{\circ} \mathrm{C}$ temperature as it was a derivatization reagent.

\section{Standard preparation}

The standard methodology [28] was followed for analysis of 15 amino acids (lysine, aspartic acid, serine, threonine, glutamic acid, cysteine, glycine, alanine, valine, methionine, isoleucine, leucine, tyrosine, phenylalanine and histidine). Each amino acid stock solution of concentration $2.5 \mathrm{mmol} / \mathrm{l}$ was prepared by dissolving each separately in $100 \mathrm{ml} 1 \mathrm{M} \mathrm{HCl}$ and diluted to the volume with triple distilled water. The working standard solution of each amino acid was prepared by diluting with eluent A using 1:20 ratio. Ninhydrin derivatized reagent was delivered and mixed at the flow rate $0.2 \mathrm{ml} / \mathrm{min}$ in the reaction column of the analyzer to let it react with amino acids at $120^{\circ} \mathrm{C}$ temperature.

\section{Sample preparation}

The mushroom sample was extracted with $0.1 \mathrm{M} \mathrm{HCl}$ by stirring with a magnetic stirrer for $30 \mathrm{~min} .1 \mathrm{ml}$ aliquot was taken in $50 \mathrm{ml}$ volumetric flask and diluted up to the mark with eluent A. and kept in the refrigerator until when required for analysis. The extracted 
mushroom sample was filtered through $0.22 \mu \mathrm{m}$ cellulose acetate membrane filter units before injection.

\section{Instrumentation}

The amino acid composition of the mushroom sample was determined with ion-chromatograph equipped with metrohm 881 compact IC pro anion, metrohm 882 compact IC plus cation, metrohm 886 professional thermostat reactor, metrohm 887 professional auto sampler and metrohm 887 professional uv-vis detector. The amino acids in the standards and in the mushroom sample were separated in the column containing the elution buffers at a temperature of $60{ }^{\circ} \mathrm{C}$ with $20-50 \mu$ injection volume at a flow rate of $0.4 \mathrm{ml} / \mathrm{min}$. Finally, products were sent to the detector and detection was achieved with a uv-vis detector at $570 \mathrm{~nm}$.

\section{Expression of data}

Each amino acid was expressed as g/100g dry weight basis and essential amino acid (EAA-geometric mean of the ratios of the essential amino acids in a protein relative to their respective amounts in reference protein/whole egg) index and biological value (BV) were calculated by using the following formulas [29].

EAA Index

$=\sqrt[7]{\frac{\text { Lys }_{p} \times(\text { Phe }+ \text { Tyr })_{p} \times \text { Leu }_{p} \times \text { His }_{p} \times \text { Ile }_{p} \times \text { Val }_{p} \times(\text { Met }+ \text { Cys })_{p}}{\text { Lys }_{s} \times(\text { Phe }+ \text { Tyr })_{s} \times \text { Leu }_{s} \times \text { His }_{s} \times \text { Ile }_{s} \times \text { Val }_{s} \times(\text { Met }+ \text { Cys })_{s}}}$

Where subscript $\mathrm{p}$ refers to the food protein; $\mathrm{s}$ the standard protein and $\mathrm{n}$ the number of amino acids (counting pairs such as methionine and cysteine as one).

Biological Value $=1.09($ EAA Index $)-11.73$

\section{RESULTS}

From the dried sample of Lentinus sajor-caju in all 15 amino acids were quantified following standard biochemical procedure [28]. The estimated amino acid amounts (g/100g) are summarized in table 1 , 2 and 3 while fig. 1 and 2 depicts the chromatogram of amino acid standards and amino acid content in mushroom sample respectively.

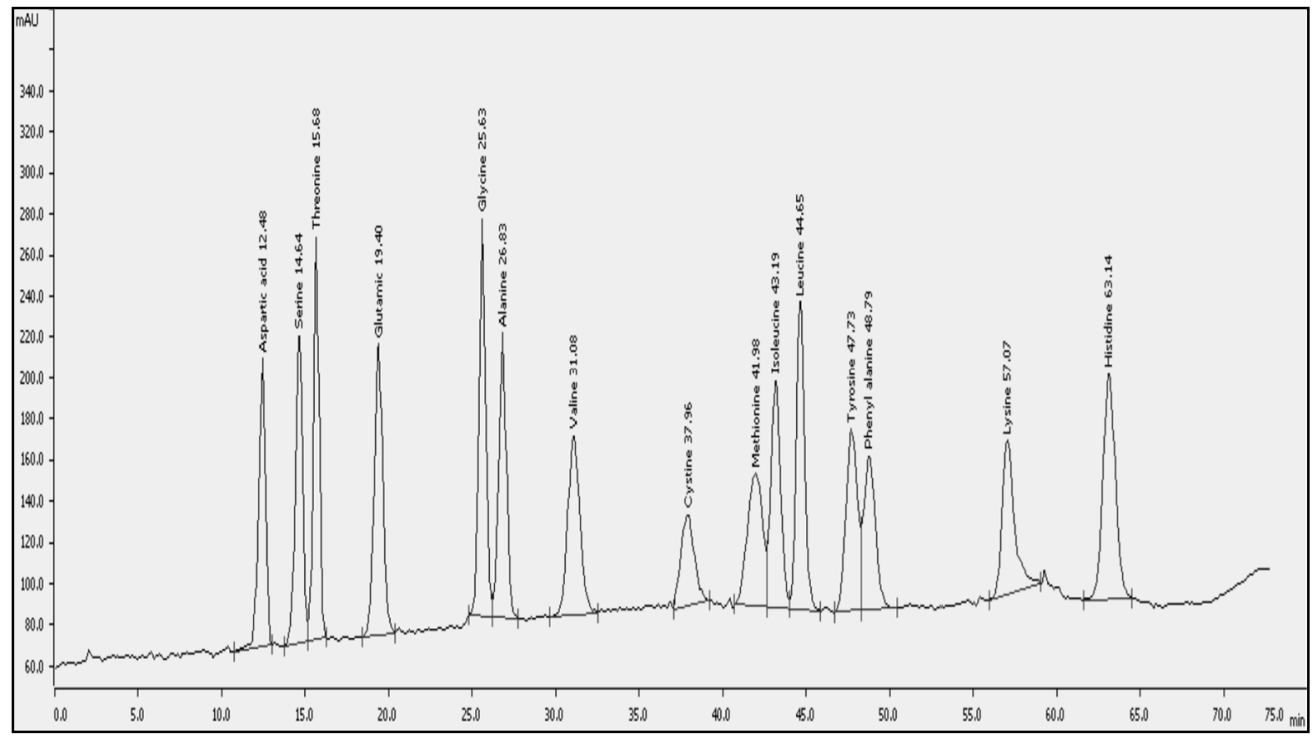

Fig. 1: Ion-exchange chromatograph of 15 standard amino acids

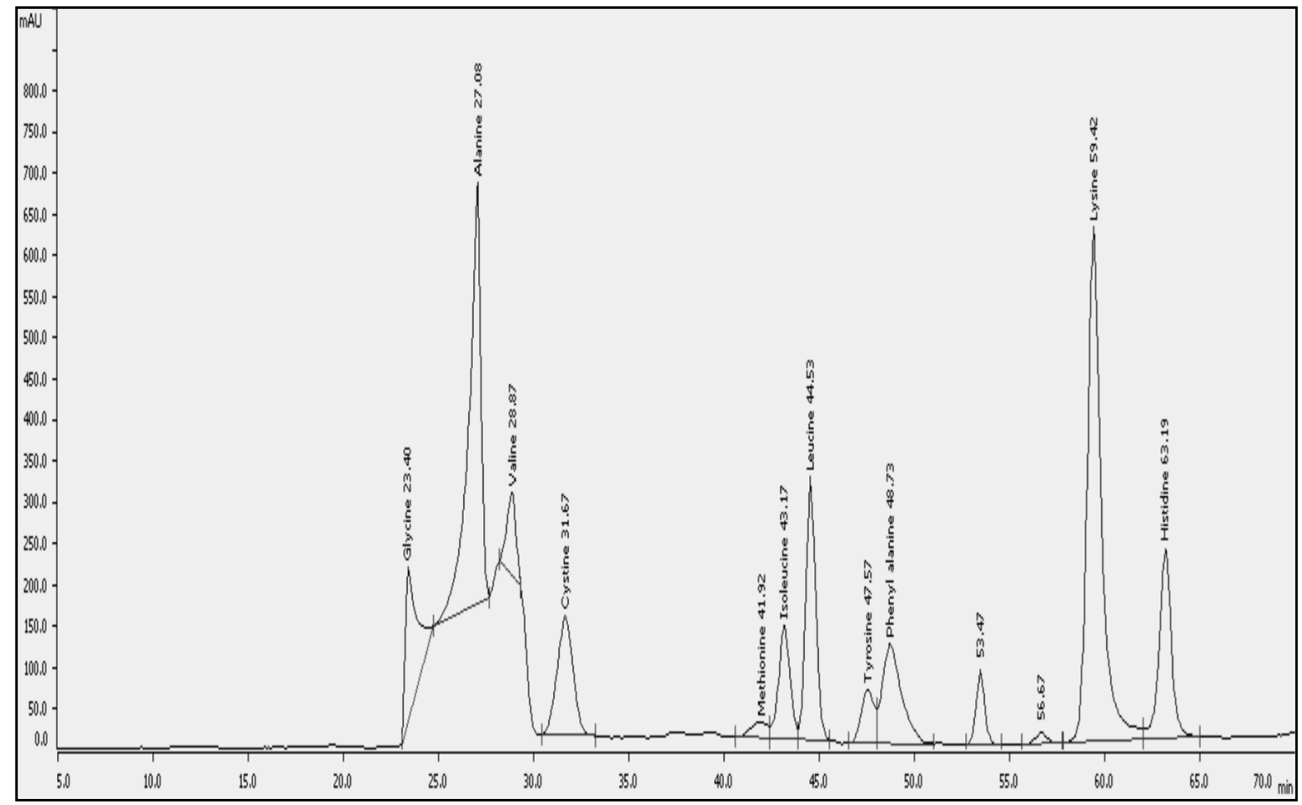

Fig. 2: Ion-exchange chromatograph amino acid profile of Lentinus sajor-caju 
The composition of analyzed amino acids revealed the presence of essential and non-essential free amino acids in varying quantity ranging from $6.66 \mathrm{~g} / 100 \mathrm{~g}$ to $0.16 \mathrm{~g} / 100 \mathrm{~g}$ in the cultivated mushroom. The total amino acid content has been evaluated at $18.82 \mathrm{~g} / 100 \mathrm{~g}$. Lysine, alanine, cysteine, phenylalanine, leucine and histidine were present in large amounts while isoleucine, tyrosine, glycine, valine and methionine in reduced amount. Glutamic acid, aspartic acid, threonine and serine were not detected during estimation.

The present work revealed that lysine $(6.66 \mathrm{~g} / 100 \mathrm{~g})$ was the preponderant essential amino acid in this mushroom. Non-essential amino acid alanine $(3.40 \mathrm{~g} / 100 \mathrm{~g})$ was found to be the second and cysteine $(1.99 \mathrm{~g} / 100 \mathrm{~g})$ third most abundant amino acid. Amongst the essential and non-essential amino acids, methionine $(0.16$ $\mathrm{g} / 100 \mathrm{~g}$ ) was observed as the least abundant amino acid. Amongst the 7 essential amino acids detected in the presently evaluated mushroom sample, lysine $(6.66 \mathrm{~g} / 100 \mathrm{~g})$, phenylalanine (1.63 $\mathrm{g} / 100 \mathrm{~g})$, leucine $(1.39 \mathrm{~g} / 100 \mathrm{~g})$ and histidine $(1.28 \mathrm{~g} / 100 \mathrm{~g})$ were detected in substantial amount in comparison to isoleucine $(0.76$ $\mathrm{g} / 100 \mathrm{~g})$, valine $(0.43 \mathrm{~g} / 100 \mathrm{~g})$ and methionine $(0.16 \mathrm{~g} / 100 \mathrm{~g})$. Amino acid threonine was not detected at all.

In the presently evaluated sample lysine $(6.66 \mathrm{~g} / 100 \mathrm{~g})$ was found to be in higher concentration in comparison to its required value $(5.20$ $\mathrm{g} / 100 \mathrm{~g}$ ) in the human diet as prescribed pattern by [30] of the amino acid requirement for 3-10 y old individual. Also in the presently evaluated mushroom sample the concentration $(2.25$ $\mathrm{g} / 100 \mathrm{~g}$ ) of aromatic amino acids (phenylalanine+tyrosine), histidine $(1.28 \mathrm{~g} / 100 \mathrm{~g})$ and concentration $(2.15 \mathrm{~g} / 100 \mathrm{~g})$ of Sulfur amino acids (methionine+cysteine) were found to be very close to the value of reference protein recommended for human nutrition [30].

Table 1: Amino acid composition of Lentinus sajor-caju (g/100g dry weight)

\begin{tabular}{lll}
\hline S. No. & Amino acid & g/100g \\
\hline Essential Amino Acids & Lysine (K) & 6.66 \\
1 & Phenylalanine (F) & 1.63 \\
2 & Leucine (L) & 1.39 \\
3 & Histidine (H) & 1.28 \\
4 & Isoleucine (I) & 0.76 \\
5 & Valine (V) & 0.43 \\
6 & Methionine (M) & 0.16 \\
7 & Threonine (T) & ND \\
8 & & 3.40 \\
Non-Essential Amino Acids & Alanine (A) & 1.99 \\
9 & Cysteine (C) & 0.62 \\
10 & Tyrosine (Y) & 0.50 \\
11 & Glycine (G) & ND \\
12 & Glutamic acid (E) & ND \\
13 & Aspartic acid (D) & ND \\
14 & Serine (S) & $\mathbf{1 8 . 8 2}$ \\
15 & & \\
\hline
\end{tabular}

$\mathrm{ND}=$ not detected

Table 2: Amino acid composition in L. sajor-caju compared to pattern by [30] of amino acid requirements for 3-10 y old individual

\begin{tabular}{|c|c|c|c|}
\hline \multicolumn{4}{|c|}{ Essential amino acid } \\
\hline S. & Amino & g/100g dry weight & FAO 2013 \\
\hline No. & acid & & \\
\hline 1 & Lysine & 6.66 & 4.8 \\
\hline 2 & Phenylalanine+Tyrosine & $1.63+0.62=2.25$ & 4.1 \\
\hline 3 & Leucine & 1.39 & 6.1 \\
\hline 4 & Histidine & 1.28 & 1.6 \\
\hline 5 & Isoleucine & 0.76 & 3.0 \\
\hline 6 & Valine & 0.43 & 4.0 \\
\hline 7 & Methionine+Cysteine & $0.16+1.99=2.15$ & 2.3 \\
\hline
\end{tabular}

In the presently evaluated mushroom sample so as to look into its nutritional quality, essential amino acid index (44.63\%), biological value (36.93\%), ratio of total essential amino acid and total amino acid (65.41\%), ratio of total non-essential amino acid and total amino acid (34.59\%), ratio of total essential amino acid and total non-essential amino acid (1.89\%), total Sulphur amino acid $(2.15 \mathrm{~g} / 100 \mathrm{~g})$ and total aromatic amino acid $(2.25 \mathrm{~g} / 100 \mathrm{~g})$ were also calculated. From the evaluated data as above, it becomes apparent that EAA Index and biological value of this mushroom are reasonably good which are the important indicators of any nutritionally rich food substrate.

Table 3: Nutritional quality evaluation

\begin{tabular}{lll}
\hline S. No. & Nutritional quality & Results \\
\hline 1 & Total Amino Acid (TAA) & $18.82 \mathrm{~g} / 100 \mathrm{~g}$ \\
2 & Total Essential Amino Acid/Total Non-Essential Amino Acid & $1.89 \mathrm{~g} / 100 \mathrm{~g}$ \\
3 & Total Sulphur Amino Acid (TSAA=Meth+Cys) & $2.15 \mathrm{~g} / 100 \mathrm{~g}$ \\
4 & Total Aromatic Essential Amino Acid (TArEAA=Phe+Tyr) & $2.25 \mathrm{~g} / 100 \mathrm{~g}$ \\
5 & Total Essential Amino Acids (\%) & $65.41 \%$ \\
6 & Essential Amino Acid (EAA) Index (\%) & $44.64 \%$ \\
7 & Total Non-Essential Amino Acid (TNEAA)/Total Amino Acid (TAA) $\%$ & $34.59 \%$ \\
8 & Biological Value (BV \%) & $36.93 \%$ \\
\hline
\end{tabular}




\section{DISCUSSION}

Mushrooms are rich sources of proteins as well as amino acids. Because of the variety of substrates used in the cultivation of edible mushrooms and their genetic profile, there is substantial variation in their amino acid content [31]. Amongst the cultivated species, the total amino acid content reported in Pleurotus ostreatus grown on different substrates have been reported to range from 35.97 $\mathrm{g} / 100 \mathrm{~g}-42.30 \mathrm{~g} / 100 \mathrm{~g}$ [32]. As compared only $18.82 \mathrm{~g} / 100 \mathrm{~g}$ total amino acid content was evaluated presently from the dried sporophores of Lentinus sajor-caju raised on the mixture of wheat straw, paddy straw, saw dust and wooden flakes substrate, which is much less in comparison to the range of total amino acids documented in oyster mushroom [32].

Pleurotus citrinopileatus worked by [33] and documented eight essential amino acids, namely leucine, valine, threonine, lysine, phenylalanine, isoleucine, methionine and tryptophan in their decreasing order of abundance. All the essential amino acids reported [34] in adequate quantity in Lentinus polychrous. However, in the case of Lentinus sajor-caju the order of their abundance starts with lysine followed by phenylalanine, leucine, histidine, isoleucine, valine and methionine. Threonine which has been reported [33] to be present in an abundant amount in P. citrinopileatus was found to be altogether absent in L. sajor-caju during the present investigation. The total essential amino acid percentage $(65.41 \%)$ documented in the cultivated sample of L. sajor-caju is substantially low in comparison to the average range of essential amino acid percentage reported [35] for cultivated (42.91\%-43.67\%) and wild mushrooms $(42.90 \%-43.73 \%)$. It is even less than the total essential amino acid percentage (34.65\%) documented for Tricholoma matsutake [36].

However amongst the essential amino acids documented in the presently investigated species, lysine $(6.66 \mathrm{~g} / 100 \mathrm{~g})$ which is vital for hormone production and bone formation [37] is present in substantial amount in comparison to its amount in Lentinus connatus $(2.15 \mathrm{~g} / 100 \mathrm{~g})$ as documented 38], Lentinus polychrous (1.74 $\mathrm{g} / 100 \mathrm{~g}$ ) as documented [38], Agaricus bisporus (3.57 g/100g) and Pleurotus florida $(3.20 \mathrm{~g} / 100 \mathrm{~g})$ as documented by [39]. Even it is much higher than reported for Pleurotus species $(5 \mathrm{~g} / 100 \mathrm{~g})$ by [40] and Agaricus bohusii (1.5\%) by [41]. However higher percentage of lysine [42] in Agaricus species (6.26\%) and Pleurotus sajor-caju (6.33\%)which is comparable to the net amount of lysine $(6.66$ $\mathrm{g} / 100 \mathrm{~g}$ ) evaluated in L. sajor-caju during the present investigations. The deficiency of this amino acid has been reported to result in anemia and chronic fatigue syndrome [37]. L. sajor-caju being a good source of lysine can be of immense utility to take care of the lysine deficiency problems by making it an obligatory part of human diet.

Phenylalanine $(1.63 \mathrm{~g} / 100 \mathrm{~g})$ was found to be the second most abundant exogenous amino acid in L. sajor-caju. This amount is slightly less than the amount of this amino acid documented in Pleurotus ostreatus $(2 \mathrm{~g} / 100 \mathrm{~g})$ by [40], in Lentinus connatus $(1.90$ $\mathrm{g} / 100 \mathrm{~g}$ ) by [38], in Agaricus abruptibulbus (1.92 g/100g) by [43] and on the higher side in comparison to its range $(1.27 \mathrm{~g} / 100 \mathrm{~g}-1.44$ $\mathrm{g} / 100$ ) documented by [32] in Pleurotus ostreatus. While working with Agaricus species, much higher amount of this amino acid $(6.67 \%)$ was documented by [42] while much less percentage $(0.65 \%)$ of this amino acid was also documented by [33] in Pleurotus citrinopileatus. Higher amount of phenylalanine $(3.28 \mathrm{~g} / 100 \mathrm{~g})$ was reported by [34] in Lentinus polychrous while [41] documented its much less percentage (0.60\%) in Agaricus bohusii. This amino acid has been reported to serve as a precursor of tyrosine, which in turn is the precursor of neurotransmitters and is a powerful antidepressant [37].

Different workers have been reported the variable amount of leucine in different edible mushrooms which is a potent stimulator of insulin [37]. The amount of this amino acid evaluated during the present investigations in L. sajor-caju $(1.39 \mathrm{~g} / 100 \mathrm{~g})$ is almost comparable to its percentage documented in Pleurotus citrinopileatus $(1.07 \%)$ by [33]. However, comparatively much lower amount of leucine has been reported in P. sajor-caju $(0.46 \%)$ by [42]. There are number of reports including that for Lentinus connatus $(2.29 \mathrm{~g} / 100 \mathrm{~g})$ [38], for Pleurotus species $(4.4 \mathrm{~g} / 100 \mathrm{~g})$ [40], for $P$. ostreatus (1.76 g/100g-2.31 g/100g) [32], for Agaricus species
(14.2\%) [42], for Agaricus bohusii (2.7\%) [41] and for Lentinus polychrous $(7.64 \mathrm{~g} / 100 \mathrm{~g}$ ) [34] where the presence of much higher percentage of leucine has been reported in comparison to its amount $(1.39 \mathrm{~g} / 100 \mathrm{~g})$ in the presently evaluated sample of L. sajor-caju. Deficiency of leucine has been reported to result in chronic fatigue syndrome [37].

Histidine which has a role in the formation of RBCs and WBCs and treatment of rheumatoid arthritis [37] is present in fairly comparable amount $(1.28 \mathrm{~g} / 100 \mathrm{~g})$ in L. sajor-caju in comparison to its percentage documented in $P$. ostreatus $(1.03 \mathrm{~g} / 100 \mathrm{~g}-1.10$ $\mathrm{g} / 100 \mathrm{~g}$ ) by [32], but it is on the lower side than documented by [40] in Pleurotus species $(2.1 \mathrm{~g} / 100 \mathrm{~g})$, Lentinus polychrous $(1.82 \mathrm{~g} / 100 \mathrm{~g})$ [34], Lentinus connatus $(1.45 \mathrm{~g} / 100 \mathrm{~g})$ [38] and almost more than double in comparison to its percentage documented in $P$. citrinoplieatus $(0.51 \%)$ [33]. Much less amount of histidine in Agaricus bohusii (0.3\%) was reported by [41]. Much higher quantity of histidine $(8.26 \mathrm{~g} / 100 \mathrm{~g})$ in Agaricus abruptibulbus was documented by [43]. The concentration of histidine $(1.28 \mathrm{~g} / 100 \mathrm{~g})$ in the presently evaluated sample was found to be very close to the suggested pattern of amino acid [30].

Amongst the essential amino acids documented in L. sajor-caju in comparison to lysine $(6.66 \mathrm{~g} / 100 \mathrm{~g})$, phenylalanine $(1.63 \mathrm{~g} / 100 \mathrm{~g})$, leucine $(1.39 \mathrm{~g} / 100 \mathrm{~g})$ and histidine $(1.28 \mathrm{~g} / 100 \mathrm{~g})$ much less percentage of isoleucine $(0.76 \mathrm{~g} / 100 \mathrm{~g})$, valine $(0.43 \mathrm{~g} / 100 \mathrm{~g})$ and methionine $(0.16 \mathrm{~g} / 100 \mathrm{~g})$ has been evaluated. Almost comparable percentage of isoleucine $(0.61 \%)$ has been reported in $P$. citrinopileatus by [33], while in P. ostreatus $(1.10 \mathrm{~g} / 100 \mathrm{~g}-1.26$ $\mathrm{g} / 100 \mathrm{~g})$, in Lentinus connatus (1.35 g/100g) and in Agaricus bohusii (1.8\%) much higher percentage of this amino acid has been documented $[32,38,41]$ respectively. In comparison, presence of 5.8 $\mathrm{g} / 100 \mathrm{~g}$ of isoleucine was reported by [40] in unidentified species of Pleurotus, $9.46 \mathrm{~g} / 100 \mathrm{~g}$ of isoleucine in Agaricus abruptibulbus was documented by [43] and $3.61 \mathrm{~g} / 100 \mathrm{~g}$ of this amino acid was reported in Lentinus polychrous [34] which is still on the higher side in comparison to the percentage of its occurrence in all other mushrooms discussed above. Like other amino acids, isoleucine is also important for human health. It is reported to have a role in the formation of hemoglobin and regulation of blood sugar and energy level and its deficiency has been reported to result in chronic fatigue syndrome [37].

Substantially higher percentage of valine $(4.65 \mathrm{~g} / 100 \mathrm{~g})$, which has a role in tissue repair [37], has been documented in Pleurotus species [40], in P. ostreatus (1.42 g/100g-1.63 g/100) [32], in P. sajor-caju $(7.81 \%)$ [42], in P. citrinopileatus $(0.85 \%)$ [33], in Lentinus polychrous (5.42 g/100g) [34], in L. connatus (1.62 g/100g) [38], in Agaricus abruptibulbus (4.18 g/100g) 43] and in Agaricus bohusii (3\%) [41] as compared to the percentage of its occurrence 0.43 $\mathrm{g} / 100 \mathrm{~g}$ ) in L. sajor-caju.

Amongst the essential amino acids evaluated in L. sajor-caju, lowest amount was documented for methionine $(0.16 \mathrm{~g} / 100 \mathrm{~g})$, which is substantially on the lower side than documented in $P$. citrinopileatus $(0.30 \%)$ by [33], P. ostreatus $(0.42 \mathrm{~g} / 100 \mathrm{~g}-0.53 \mathrm{~g} / 100 \mathrm{~g})$ by [32], $P$. florida $(1.84 \mathrm{~g} / 100 \mathrm{~g})$ by [39], Agaricus bisporus $(0.98 \mathrm{~g} / 100 \mathrm{~g})$ by [39], Pleurotus species (1.26 g/100g) by [40], Agaricus abruptibulbus $(1.62 \mathrm{~g} / 100 \mathrm{~g})$ by [43], Lentinus polychrous $(2.25 \mathrm{~g} / 100 \mathrm{~g})$ by [33] and L. connatus $(0.55 \mathrm{~g} / 100 \mathrm{~g})$ by [38]. Almost comparable amount of methionine $(0.1 \%)$ has been documented in Agaricus bohusii [41]. Methionine is reported to assist in the breakdown of fats and also serves as an antioxidant [37].

Out of the non-essential amino acids, alanine (18\%-45\%) which is a major part of connective tissues and help to boost immune system [37] has been reported to be the main component in almost all the mushrooms [44]. Presently also in L. sajor-caju, alanine (3.40 $\mathrm{g} / 100 \mathrm{~g}$ ) which has a role in the sugar metabolism and boosting the immune system [44], was found in maximum proportion in comparison to cysteine $(1.99 \mathrm{~g} / 100 \mathrm{~g})$, tyrosine $(0.62 \mathrm{~g} / 100 \mathrm{~g})$ and glycine $(0.50 \mathrm{~g} / 100 \mathrm{~g})$. The documented amount of alanine in the presently investigated species is almost comparable to its amount in Lentinus connatus $(3.74 \mathrm{~g} / 100 \mathrm{~g})$ by [38] and Pleurotus ostreatus $(3.55 \mathrm{~g} / 100 \mathrm{~g})$ as reported by [32]. However, in comparison much less percentage of alanine (1.60\%) has been documented in Agaricus 
bisporus [42] and in Agaricus bohusii (0.8\%) [41]. In five wild edible species of Lentinus, namely L. sajor-caju, L. connatus, L. torulosus, $L$. cladopus and $L$. squarrosulus, the alanine content has been reported to range from $0.09 \%-0.15 \%$ [45]. Also amongst the five wild Pleurotus species evaluated by [46], maximum $(0.19 \%)$ percentage of alanine was documented in P. pulmonarius, which is much less in comparison to the proportion of alanine present in L. sajor-caju $(3.40 \mathrm{~g} / 100 \mathrm{~g})$. The documented amount of alanine in the presently investigated species is much less in comparison to its amount in Agaricus abruptibulbus (7.15 g/100g) reported by [43] and in Lentinus polychrous $(11.29 \mathrm{~g} / 100 \mathrm{~g})$ reported by [34]. This amino acid is reported to be responsible for giving sweet taste to mushroom [4].

The second most abundant non-essential amino acid evaluated in the presently investigated mushroom is cysteine $(1.99 \mathrm{~g} / 100 \mathrm{~g})$ which is a natural detoxifier and its deficiency in the body results in food allergy [37]. In comparison, much less cysteine percentage has been documented in Agaricus bisporus (0.86\%) and Pleurotus florida $(0.55 \%)$ [39]. Even in P. ostreatus $(0.46 \%-0.53 \%)$ cysteine has been documented in much less proportion [32]. Same is true for $P$. citrinopileatus in which substantially low percentage of cysteine $(0.20 \%)$ has been evaluated [33], for L. connatus (0.43 g/100g) [38] and for Agaricus bohusii (0.1\%) by [41]. However, in Lentinus polychrous almost comparable $(1.92 \mathrm{~g} / 100 \mathrm{~g})$ amount of cysteine has been documented [34]. In comparison, high cysteine quantity has been documented in Agaricus abruptibulbus ( $2.75 \mathrm{~g} / 100 \mathrm{~g}$ ) by [43].

Tyrosine, which is a precursor of neurotransmitters-dopamine, norepinephrine, epinephrine and melanin [37], has been documented in very less $(0.62 \mathrm{~g} / 100 \mathrm{~g})$ proportion in $L$. sajor-caju during the present investigation in comparison to $0.81 \%-1.13 \%$ tyrosine reported in Pleurotus ostreatus[32], Agaricus bohusii (1.4\%) by [41], Lentinus polychrous $(5.52 \mathrm{~g} / 100 \mathrm{~g})$ by [34], L. connatus $(1.43 \mathrm{~g} / 100 \mathrm{~g})$ by [38] and P. sajor-caju (3.36\%) by [42]. However, in $P$. citrinopileatus almost comparable (0.58\%) amount of tyrosine has been documented [33]. While working with five edible Lentinus species from North-West India, tyrosine content ranged from $0.16 \%-0.24 \%$ [45] and in five wild Pleurotus species ranged from $0.14 \%-0.20 \%$ [46], with maximum in P. sapidus $(0.20 \%)$. As in all other edible mushrooms, the presence of tyrosine in the presently investigated mushroom adds to the nutraceutically credentials of $L$. sajor-caju, as the deficiency of this amino acid has been reported to result in hypothyroidism.

Glycine, although the present in substantially low $(0.50 \mathrm{~g} / 100 \mathrm{~g})$ amount in L. sajor-caju, is an important structural constituent of hemoglobin and its deficiency results in hypoglycemia and anemia [37]. It is an integral part of commonly cultivated mushrooms including Agaricus bisporus (3.02\%) and Pleurotus sajor-caju (11.1\%) as documented by [42]. In the case of Pleurotus ostreatus, glycine content ranged from $0.43 \mathrm{~g} / 100 \mathrm{~g}$ to $1.65 \mathrm{~g} / 100 \mathrm{~g}$ [32], which is almost comparable to the amount of glycine documented in $L$. sajor-caju $(0.50 \mathrm{~g} / 100 \mathrm{~g})$. Another oyster mushroom, Pleurotus citrinopileatus, also possesses glycine $(0.84 \%)$ in the proportionate amount [33]. However, in Agaricus abruptibulbus (3.21 g/100g) much higher amount of glycine has been documented [43], in Agaricus bohusii (1.9\%) [41], in Lentinus polychrous (5.55 g/100g) by [34] and in L. connatus $(1.55 \mathrm{~g} / 100 \mathrm{~g})$ by [38].

\section{CONCLUSION}

Lentinus sajor-caju (Fr.) Fr. is a potential source of quality protein with a substantial proportion of exogenous and endogenous amino acids. In view of its nutritional quality parameters, amino acids composition and the presence of some such amino acids as lysine, phenylalanine, leucine, histidine amongst the exogenous amino acids and alanine, cysteine, tyrosine and glycine amongst the nonessential amino acids, this mushroom can be a good food supplement.

\section{ACKNOWLEDGMENT}

Both the authors designed the experiment, analysed the data and written the manuscript. The authors are thankful to Head Department of Botany, Punjabi University, Patiala, Punjab, India for providing laboratory facilities. This work was funded by University Grants Commission with a grant under DRS Phase-III (SAP) Program.

\section{CONFLICT OF INTERESTS}

The authors do not have any conflict of interests

\section{REFERENCES}

1. Prabu M, Kumuthakalavalli R. Antioxidant activity of oyster mushroom (Pleurotus florida [Mont.] Singer) and milky mushroom (Calocybe indica P and C). Int J Curr Pharma Res 2016;8:48-51.

2. Nyman J. Incorporation of arginine, ornithine and phenylalanine into tropane alkaloids in suspension-cultured cells and aseptic roots of intact plants on Atropa belladonna. J Exp Bot 1994;45:979-86.

3. Chang ST, Miles G. The nutritional attributes of edible mushrooms. In: Mushroom cultivation, nutritional value, medicinal effects and environmental impact. Ed 2nd. Boca Raton, London, New York Washington, DC; 2004. p. 27-36.

4. Voet D, Voet JG. Biochemistry. Wiley, Hoboken, New Jersey; 2004.

5. Gruen EH, Wong MW. Distribution of cellular amino acids, protein and total organic nitrogen during fruit body development in Flammulina veluptipes. Can J Biol 1982;60:1330-41.

6. Khanna PK, Garcha HS. Pleurotus mushroom-a source of food protein. Mushroom News Trop 1984;4:9-14.

7. Breene WM. The nutritional and medicinal value of specialty mushrooms. J Food Prot 1990;53:883-94.

8. Tseng YH, Mau JL. Contents of sugars, free amino acids and free 5'-nucleotides in mushrooms Agaricus bisporus during postharvest storage. J Sci Food Agric 1999;79:1519-23.

9. Tsai SY, Wu TP, Huang SJ, Mau JL. Nonvolatile taste components of Agaricus bisporus harvested at different stages of maturity. Food Chem 2007;103:1457-64.

10. Jandaik CL, Kapoor JN. Amino acid composition of Pleurotus sajor-caju (Fr.) sing. Mushroom J 1976;41:154-6.

11. Samajpati N. Nutritive value of some Indian edible mushrooms. Mushroom Sci 1978;10:695-703.

12. Bano Z, Bhagya S, Srinivasan KS. Essential amino acid composition and proximate analysis of the mushrooms, Pleurotus eous and Pleurotus florida. Mushroom Newsl Trop 1981;1:6-10.

13. Khanna PK, Garcha HS. Pleurotus mushroom-a source of food protein. Mushroom News Trop 1984;4:9-14.

14. Khanna PK, Garcha HS. Nucleic acid content and relative nutritive value of sporophore proteins of Pleurotus species. Mushroom News Trop 1986;6:17-20.

15. Bisaria R, Madan N, Bisaria VS. Mineral content of mushroom Pleurotus sajor-caju cultivated on different agro residues. Mushroom J Trop 1987a;7:53-60.

16. Bisaria R, Madan N, Bisaria VS, Mukhopadhyay SN. Amino acid composition of mushroom Pleurotus sajor-caju cultivated on different agro residues. Biol Wast 1987b;20:251-9.

17. Hira CK, Vadhera S, Mann APS. Biochemical changes in sporophores of two mushroom species before and after the opening of caps. Ann Biol 1990;6:95-9.

18. Atri NS, Sharma SK, Joshi R, Gulati A, Gulati A. Nutritional and nutraceutical composition of five wild culinary-medicinal species of genus Pleurotus (higher basidiomycetes) from northwest India. Int J Med Mushroom 2013;15:49-56.

19. Kumari Babita, Upadhyay RC, Atri NS. Evaluation of nutraceutical components and antioxidant potential of North Indian wild culinary medicinal termitophilous mushrooms. Int J Med Mushroom 2013;15:189-95.

20. Rathore MS, Gupta VB. Protective effect of amino acids on eye lenses against oxidative stress induced by hydrogen peroxide. Asian J Pharma Clin Res 2010;3:166-9.

21. Obreshkova DP, Tsvetkova DD, Ivanov KV. Simultaneous identification and determination of the total content of amino acids in food supplements-tablets by gas chromatography. Asian J Pharma Clin Res 2012;5:57-68.

22. Purkayastha RP, Chandra A. Manual of Indian Edible Mushrooms. New Delhi; 1985. 
23. Verma RN, Singh BG, Singh SM. Mushroom flora of North Eastern Hills. In: Chadha KL, Sharma SR. ed. Advances in Horticulture. New Delhi, India; 1995. p. 35-62.

24. Chin FH. Edible and poisonous fungi from the forest of Sarawak. Part 1. Sar Mushroom J 1981;50:211-25.

25. Corner EJH. The agaric genera Lentinus, Panus and Pleurotus with particular references to Malaysian species. Nova Hedwigia Beih; 1981. p. 69-169.

26. Pegler DN. The genus Lentinus-A World Monograph. London; 1983.

27. Atri NS, Kaur Amanjeet, Kour Harwinder. Wild mushroomscollection and identification. In: RD Rai, RC Upadhyay, SR Sharma. Ed. Frontiers in Mushroom Biotechnology. Solan, India; 2005. p. 9-26.

28. AOAC. Lysine, methionine and threonine in feed grade amino acids and premixes. Official Methods Anal AOAC 1999;999:13.

29. Oser BL. An integrated essential amino acid index for predicting the biological value of proteins. In: AA Albanese. Ed. Protein and amino acid nutrition. New York, London; 1959. p. 281-91.

30. FAO. Dietary protein quality evaluation in human nutrition report of FAO expert consultation. Food and Agricultural organization of the United Nations Rome, Food and Nutr; 2013. p. 92.

31. Diez VA, Alvarez A. Compositional and nutritional studies on two wild edible mushrooms from north-west Spain. Food Chem 2001;75:417-22.

32. Oyetayo VO, Ariyo 00. Micro and macro nutrient properties of Pleurotus ostreatus (Jacq: Fries) cultivated on different wood substrates. J Biol Sci 2013;6:223-6.

33. Musieba F, Okoth S, Mibey RK, Wanjiku S, Moraa K. Proximate composition,amino acids and vitamins profile of Pleurotus citrinopileatus singer: an indigenous mushroom in Kenya. Am J Food Technol 2013;8:200-6.

34. Ravikrishnan V, Naik P, Ganesh S, Rajashekhar M. Profile of mushroom Lentinus polychrous Lév, from Western Ghats, Southern India. Int J Plant Anim Environ Sci 2015;5:278-81.

35. Oyetayo FL, Akindahunsi AA, Oyetayo VO. Chemical profile and amino acids composition of edible mushroom Pleurotus sajorcaju. Nutr Health 2007;18:383-9.
36. Liu GH, Wang B, Zhou XG, Hu X. Compositional analysis and nutritional studies of Tricholoma matsutake collected from South west China. J Med Plant Res 2010;4:1222-7.

37. Afiukwa CA, Ebem EC, Igwe DO. Characterization of the proximate and amino acid composition of edible wild mushroom species in Abakaliki, Nigeria. Am Assoc Sci Technol J Biosci 2015;1:20-5.

38. Garcha HS, Khanna PK, Soni GL. Nutritional importance of mushrooms. In: Chang ST, Buswell JA, Chiu S. Ed Mushroom Biology and Mushroom Products. Chinese University, Hong Kong; 1993. p. 227-36.

39. Bano Z, Srinivasan KS, Srivastava HC. Amino acid composition of the protein from mushroom Pleurotus (species). Appl Microbiol 1963;11:184-7.

40. Lacheva M. Morphological and biochemical study of Bulgarian species Agaricus bohusii. J Biol Environ Sci 2014;4:32-9.

41. Mdachi SJM, Nkunya MHH, Nyigo VA, Urasa IT. Amino acid composition of some tanzanian wild mushrooms. Food Chem 2004;86:179-82.

42. Wu G. Amino acids: metabolism, functions and nutrition. Amino Acids 2009;37:1-17.

43. Naga MS, Kandikere RS. Nutritional composition of two wild mushrooms consumed by the tribals of the Western Ghats of India. Mycology 2014;5:64-72.

44. Ribeiro B, Andrade AB, Silva BM, Baptista P, Seabra RM, Valentao P. Comparative study on free amino acid composition of wild edible mushroom species. J Agric Food Chem 2008;56:10973-9.

45. Sharma SK, Atri NS, Joshi R, Gulati A, Gulati A. Evaluation of wild edible mushrooms for amino acid composition. Acad J Plant Sci 2012;5:56-9.

46. Atri NS, Sharma SK, Joshi R, Gulati A, Gulati A. Amino acid composition of five wild Pleurotus species chosen from North West India. Eur J Biol Sci 2012;4:31-4.

\section{How to cite this article}

- Lata, Narender Singh Atri. Amino acid profile of a basidiomycetous edible mushroom-Lentinus sajor-caju. Int J Pharm Pharm Sci 2017;9(9):252-257. 